\title{
Action of rain on formulations of glyphosate mixed with saflufenacil for the control of Brachiaria decumbens
}

\section{Ação da chuva em formulações de glyphosate em mistura com saflufenacil no controle de Brachiaria decumbens}

\author{
Andréia Cristina Rodrigues da Costa ${ }^{1}$, Clebson Gomes Gonçalves ${ }^{2 *}$, Antonio Carlos da Silva Junior ${ }^{2}$, \\ Leonildo Cardoso ${ }^{3}$, Dagoberto Martins ${ }^{2}$
}

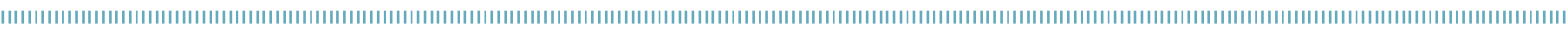

\begin{abstract}
This study aimed to evaluate the effects of rain on the efficiency of different formulations of glyphosate applied in isolation and in combination with saflufenacil on the control of Brachiaria decumbens. This study was conducted during the first half of 2013. The treatments consisted of an isolated application of three formulations of glyphosate (Roundup Original, Roundup Transorb R, and Roundup WG) at 1,080 g a.e. $\mathrm{ha}^{-1}$ and mixed with saflufenacil at $24.5 \mathrm{~g}$ a.e. $\mathrm{ha}^{-1}+$ Dash at $0.5 \% \mathrm{v} / \mathrm{v}$ at six time intervals of simulated rain: $15,30,60$, 120, 240 and 360 minutes after application of herbicides and a control treatment without rain. We performed visual evaluations of plant control at 4, 7, 14, 21 and 28 days after application of herbicides. The mixture of saflufenacil + Dash with the original Roundup formulations, Roundup Transorb R and Roundup WG increased the control speed of B. decumbens plants regardless of the rain interval studied. The formulations of glyphosate (Roundup Transorb R and Roundup WG) applied in isolation were affected by rains that occurred shortly after spraying. In combination with saflufenacil + Dash, there was a synergistic effect on weed control.
\end{abstract}

KEYWORDS: Brachiaria; efficacy; herbicide; weed.
RESUMO: O objetivo do trabalho foi avaliar a ocorrência de chuvas na eficiência de diferentes formulaçóes de glyphosate aplicadas de forma isolada e em mistura com o saflufenacil, sobre o controle de Brachiaria decumbens. O estudo foi realizado no primeiro semestre de 2013. Os tratamentos constaram da aplicação isolada de três formulaçóes de glyphosate (Roundup Original, Roundup Transorb R e Roundup WG) a 1.080 g e.a. ha ${ }^{-1}$ e em mistura com o saflufenacil a 24,5 g i.a. ha $^{-1}+$ Dash a $0,5 \%$ v/v e, seis intervalos de tempo para simulação da chuva: $15 ; 30 ; 60 ; 120 ; 240$ e 360 minutos após a aplicação dos herbicidas e uma testemunha sem chuva. Foram realizadas avaliaçóes visuais de controle das plantas aos 4; 7; 14; 21 e 28 dias após a aplicaçáo dos herbicidas. A mistura de saflufenacil + Dash às formulações de Roundup original, Roundup transorb R e Roundup WG aumentaram a velocidade de controle das plantas de $B$. decumbens, independente do intervalo de chuva estudado. As formulaçôes de glyphosate (Roundup Transorb R e Roundup WG) aplicados isolados foram afetadas por chuvas que ocorreram logo após a pulverização e quando em mistura com saflufenacil + Dash observou-se efeito sinérgico no controle das plantas daninhas.

PALAVRAS-CHAVE: Brachiaria; eficácia; herbicida; plantas daninhas.

\footnotetext{
'Universidade Estadual de Maringá (UEM) - Umuarama (PR), Brazil.

${ }^{2}$ Faculdade de Ciências Agrárias e Veterinárias (FCAV), Universidade Estadual Paulista “Júlio de Mesquita Filho" (Unesp) - Jaboticabal (SP), Brazil. ${ }^{3}$ Faculdade de Medicina, UNESP - Botucatu (SP), Brazil.

*Corresponding author: goncalvescg.agro@hotmail.com Received on: 12/08/2015. Accepted on: 09/25/2017
} 


\section{INTRODUCTION}

The presence of weeds is one of the most important factors affecting an agricultural economy on a permanent basis, as crops are subject to a series of environmental actions that directly or indirectly influence their growth, development and productivity.

Species such as Brachiaria decumbens compete with crops for physical space, promote competition for environment resources such as water, light and nutrients, may be hosts for pests and diseases, and interfere with the harvesting process by reducing the speed of movement of harvesters or even by clogging them (SILVA et al., 2008; 2009).

For an efficient control of species such as Brachiaria and a reduction in production costs, the use of herbicides such as glyphosate has been a management alternative, especially when using direct sowing in straws. The development of resistant glyphosate cultures has led to a marked increase in the use of this herbicide, since it is used to desiccate a broad spectrum of annual and perennial weed species.

It should be noted that the application of glyphosate on a large scale has successively caused a very large selection pressure on agricultural areas, resulting in selection and predominance of weeds that are difficult to control and resistant biotypes (JONES et al., 2005; VILA-AIUB et al., 2007; OWEN, 2008; CARVALHO et al., 2011; GAINES et al., 2012).

In order to increase levels of effective control of this species and reduce production costs, new alternatives have been researched. The use of glyphosate mixed with other herbicides has been shown to be a control strategy with a high use potential (YAMAUTI et al., 20 Io; MACIEL et al., 2011; STEWART et al., 2011; ALONSO et al., 2013; GONÇALVES et al., 2016).

Saflufenacil is an herbicide inhibitor of the proto-porphyrinogen IX oxidase enzyme (PPO or PROTOX) used during post-emergence for a broad control of eudothycotton weeds (GROSSMANN et al., 2010). It is noteworthy that, in a study conducted by EUBANK et al., (2013), the authors observed that the spray of saflufenacil mixed with glyphosate for the control of glyphosate-resistant Conyza canadensis provided an additive effect on the control of this species.

The interactions between saflufenacil and glyphosate in tank mix also provided a better control of Panicum texanum when compared to the isolated application of saflufenacil (SINGH et al., 2011). This indicated that saflufenacil has a great potential when mixed with glyphosate as an alternative for the control of broadleaf weeds and grasses.

However, herbicide uptake and translocation are limited by the volume that crosses leaf cuticles, and this is significantly influenced by climatic conditions, molecular structure of weed species and characteristics of herbicides and their adjuvants (FENG et al., 2000).

Studies conducted to demonstrate the effects of rain on the efficacy of glyphosate after post-emergence application have shown that this herbicide decreases its control efficiency when rain occurs soon after its application (MARTINI et al., 2003; SOUZA et al., 2013; 2014). However, control efficacy is also directly influenced by the various formulations available in the market and by the dose used (FENG et al., 2000; MONQUERO; SILVA, 2007).

Due to a lack of knowledge on the possible effects of rain on the efficacy of saflufenacil in tank mixes, it is of fundamental importance that studies be carried out to better exploit the potential of this new herbicide. Therefore, this study aimed to evaluate different rain intervals between sprayings of glyphosate using different formulations (Roundup original, Roundup Transorb R and Roundup WG), isolated and mixed with saflufenacil, and the influence of rain on the control of Brachiaria decumbens.

\section{MATERIALS AND METHODS}

The study was conducted at the NUPAM (Núcleo de Estudos Avançados em Matologia), belonging to FCA/UNESP, campus of Botucatu/SP, during the first semester of 2013. In order to provide optimum growth conditions for Brachiaria decumbens plants, the seeds were sown in plastic pots with a soil capacity of $1.5 \mathrm{~L}$, and placed in a greenhouse.

The soil was fertilized with the NPK formulation 04-14-08, and corrected using dolomitic limestone according to soil analysis and fertilization recommendation of the Bulletin 100 for Corn Crops (RAIJ et al., 1996). After the emergence of seedlings, a thinning was performed, and only one plant per pot was stacked. The treatments were applied when plants were 16-20 cm high (6-8 leaves).

The study was completely randomized with four replicates arranged in a $7 \times 7$ factorial design (seven chemical treatments for seven rain exposure periods), in addition to one control treatment without application of herbicides.

The treatments consisted of spraying isolated glyphosate using three commercial formulations: Roundup Original (isopropylamine salt), Roundup Transorb R (potassium salt) and Roundup WG (ammonium salt) at 1,080 g a.e. ha $\mathrm{ha}^{-1}$ and mixed with saflufenacil at $24.5 \mathrm{~g}$ a.i. $\mathrm{ha}^{-1} .0 .5 \% \mathrm{v} / \mathrm{v}$ of Dash adjuvant was added to the isolated saflufenacil treatment and mixed with the three formulations of glyphosate.

For the application of herbicides, a stationary spraying system was used, pressurized by air and equipped with a $2 \mathrm{~L}$ reservoir. The equipment was regulated to provide a consumption of $200 \mathrm{~L} \mathrm{ha}^{-1}$. The application bar was equipped with four "Teejet" XR 11002VS flat jet tips spaced $50 \mathrm{~cm}$ apart. The environmental characteristics at the time of application were: temperature of $25-28^{\circ} \mathrm{C}$ and $\mathrm{RH}$ of $76-81 \%$ (beginning and end of spraying).

After the application of herbicides, a $20 \mathrm{~mm}$ rainfall was simulated out for 10 minutes using a stationary 
simulator at the following time intervals after application of herbicides: $15 \mathrm{~min}, 30 \mathrm{~min}, 1,2,4$ and $6 \mathrm{~h}$, plus a treatment without rain. After the spraying of herbicides and the simulation of rains, visual control assessments were performed at 4, 7, 14, 21 and 28 days after application of herbicides using a graded percentage scale, in which 0 (zero) corresponded to no injuries and 100 corresponded to plant death, according to the BRAZILIAN SOCIETY OF WEED SCIENCE (1995).

The parameters used to establish visual control scores were growth inhibition, quantity and uniformity of injuries, tillering capacity and dead plants.

The results were submitted to analysis of variance by $\mathrm{F}$ test. The means of the treatments were compared by Tukey test at $5 \%$.

\section{RESULTS AND DISCUSSION}

We observed, in the first evaluation at 4 DAA (days after application), that the isolated application of different formulations of glyphosate caused symptoms of phytotoxicity to Brachiaria decumbens plants only when there was no rain, which evidenced a negative effect of rainfall on the control of this weed (Table 1).

However, when saflufenacil + Dash was applied in isolation and the formulations of glyphosate were sprayed in tank mix with saflufenacil + Dash, phytotoxicity symptoms were observed in B. decumbens plants in all periods studied (Table 1).
The addition of saflufenacil + Dash to the tank mix with the different formulations of glyphosate initially provided a greater control of $B$. decumbens plants. There were also effects caused by the different rain periods evaluated. In general, for all formulations of glyphosate analyzed and for the isolated application of saflufenacil, we noted that the later the occurrence of rain, the greater the control of $B$. decumbens plants (Table 1).

At 7 DAA, an initial recovery of injuries was observed in B. decumbens plants. This was caused by the isolated application of saflufenacil + Dash. Only plants not subjected to rain presented phytotoxicity symptoms (Table 2 ).

When comparing the mixtures of glyphosate with saflufenacil + Dash with the isolated application of different formulations of glyphosate, a positive effect of the tank mix was observed for most rain periods studied. The benefits of saflufenacil + Dash during the first rain periods (15, 30 and $60 \mathrm{~min}$ ) after herbicide spraying in all formulations were significant, as there were significant increases in control in all situations (Table 2). When rain lasted for more than 2 hours, no gains were observed for the control, or they were similar or even lower than those observed for the 2-hour rain period for saflufenacil + Dash + Roundup WG.

An important aspect related to stress was the null control provided by the application of Roundup Transorb R (potassium salt) when rains occurred 15 min after its application, as well as the low control of Roundup WG (ammonium salt) compared to the original Roundup formulation (isopropylamine salt) (Table 2).

Table 1. Mean values for percentage of control of Brachiaria decumbens at 4 DAA obtained by the unfolding of degrees of freedom of the interaction between herbicides and periods without rain after the application of herbicides.

\begin{tabular}{|c|c|c|c|c|c|c|c|}
\hline \multirow{3}{*}{$\begin{array}{l}\text { Periods } \\
\text { Without rain }\end{array}$} & \multicolumn{7}{|c|}{ Treatments } \\
\hline & $\begin{array}{l}\text { saf. + R. } \\
\text { Original }{ }^{1}\end{array}$ & $\begin{array}{l}\text { saf. + R. } \\
\text { Transorb } \mathbf{R}^{1}\end{array}$ & saf. + R. WG ${ }^{1}$ & saflufenacil $^{1}$ & R. Original & R. Transorb & R. WG \\
\hline & $\begin{array}{l}(24.5+1,080) \\
(\text { a a.i./a.e. ha-1) }\end{array}$ & $\begin{array}{l}(24.5+1,080) \\
(g \text { a.i./a.e. ha-1) }\end{array}$ & $\begin{array}{l}(24.5+1,080) \\
(\text { g a.i./a.e. ha-1) }\end{array}$ & $\begin{array}{c}(24.5) \\
\left(\mathrm{g} \text { a.i. } h a^{-1}\right)\end{array}$ & $\begin{array}{c}(1,080) \\
\left(g \text { a.e. } h^{-1}\right)\end{array}$ & $\begin{array}{c}(1,080) \\
\left(g \text { a.e. } \text { ha }^{-1}\right)\end{array}$ & $\begin{array}{c}(1,080) \\
\left(g \text { a.e. } \text { ha }^{-1}\right)\end{array}$ \\
\hline $15 \mathrm{~min}$ & 7.3 a D & $2.3 a b c$ & $4.30 \mathrm{ab} C$ & $3.3 \mathrm{ab} B$ & 0.0 b B & 0.0 b A & $0.0 \mathrm{~b} \mathrm{~A}$ \\
\hline $30 \mathrm{~min}$ & 8.5 a D & $6.5 \mathrm{ab} C$ & $7.00 \mathrm{ab} B C$ & $3.3 \mathrm{ab} B$ & 0.0 b B & $0.0 \mathrm{~b} \mathrm{~A}$ & $0.0 \mathrm{~b} \mathrm{~A}$ \\
\hline 1 hour & 21.5 a BC & 17.8 ab B & $10.30 \mathrm{bc} \mathrm{BC}$ & $4.8 \mathrm{~cd} \mathrm{~B}$ & $0.0 \mathrm{~d} \mathrm{~B}$ & $0.0 \mathrm{~d} A$ & $0.0 \mathrm{~d} A$ \\
\hline 2 hours & 33.3 a $A B C$ & $18.5 a b B$ & $14.00 \mathrm{bc} A B$ & $8.0 \mathrm{c} \mathrm{AB}$ & $0.0 \mathrm{~d} \mathrm{~B}$ & $0.0 \mathrm{~d} A$ & $0.0 \mathrm{~d} A$ \\
\hline 4 hours & 30.0 a A & 19.0 b B & 8.80 c BC & $5.5 \mathrm{~cd} \mathrm{~B}$ & $0.0 \mathrm{~d} \mathrm{~B}$ & $0.0 \mathrm{~d} A$ & $0.0 \mathrm{~d} A$ \\
\hline 6 hours & 20.0 a C & 19.5 a B & $11.80 \mathrm{~b} \mathrm{BC}$ & $9.3 \mathrm{~b} \mathrm{AB}$ & 0.0 c B & 0.0 c A & 0.0 c A \\
\hline No Rain & 28.0 a $A B$ & 28.3 a A & 19.55 b A & 15.0 b A & 7.3 с A & $2.3 c \mathrm{~A}$ & $5.0 \mathrm{c} \mathrm{A}$ \\
\hline Treatment $(T)$ & & & & $148.65^{* *}$ & & & \\
\hline Rainfall (C) & & & & $41.35^{\star *}$ & & & \\
\hline $\mathrm{TxC}$ & & & & 5.01 ** & & & \\
\hline CV\% & & & & 42.82 & & & \\
\hline d.m.s & & & & 2.71 & & & \\
\hline
\end{tabular}

Means followed by the same lowercase letters in rows and uppercase in columns do not differ statistically by Tukey test $(P<0.05) ;{ }^{1} 0.5 \%$ Dash added, DAA: Days After Application; R: Roundup; saf.: saflufenacil; **Significant at $1 \%$ probability level. 
This was also observed by FENG et al. (2000), who reported differences between glyphosate formulations as for absorption rates. Roundup Ultra (ammonium salt) was more efficient than Sulfosate 5 (sulfosate trimethylsulfonic salt) and Roundup Original (isopropylamine salt) as for the uptake of glyphosate by Abutilon theophrasti at shorter time intervals after application. This may lead to a direct correlation between the occurrence of a rainfall, and the speed and volume of glyphosate absorbed by plants, since the efficacy of glyphosate depends on processes such as herbicide retention on leaf surface, leaf penetration, plant-to-site translocation, and EPSPS target enzyme inhibition (KIRKWOOD; MCKAY, 1994).

It can be seen, from $14 \mathrm{DAA}$, that the isolated application of saflufenacil + Dash did not cause any injuries to $B$. decumbens plants regardless of the rain period tested (Table 3 ). The isolated application of Roundup Original (isopropylamine salt) provided a total control of $B$. decumbens plants during all rainy periods analyzed, which evidences that not even one rainfall period occurring $15 \mathrm{~min}$ after spraying affected the efficiency of this formulation (Table 3).

The other formulations, Roundup Transorb R and Roundup WG, were affected by rains that occurred $15 \mathrm{~min}$ after spraying and, to a lesser extent, with one rainfall period after $30 \mathrm{~min}$ (Table 3). These results corroborate those of SOUZA et al. (2014), who, upon evaluating the occurrence of rains 15 minutes after spraying glyphosate herbicide using Roundup Transorb, Roundup Transorb R and Roundup Ultra formulations, did not observe a decrease in the control efficiency of Senna obtusifolia plants.
A different result was observed by SOUZA et al. (2013), who, upon evaluating the influence of rains on the efficiency of herbicides sprayed on Ipomoea grandifolia plants, observed that all formulations based on glyphosate decreased control when there was a rain simulation, especially regarding treatments in which rainfalls occurred soon after spraying herbicides. MONQUERO; SILVA (2007) also reported a negative impact on the efficacy of glyphosate for the control of Euphorbia heterophylla and Ipomoea purpurea with the occurrence of rains after its application.

Such apparently contradictory results found in the literature indicate that, in addition to environmental conditions at the time of application, herbicide absorption efficacy may be greatly influenced by several factors such as different formulations, concentration of herbicides and surfactants, species and phenological stages of weed development, growth habits, leaf morphology and epicuticular wax composition (KIRKWOOD; MCKAY, 1994; CHACHALIS et al., 2001a; HUANGFU et al., 2007). It should be noted that a high amount of epicuticular wax may be characterized in some species as an effective barrier to the absorption of herbicides (CHACHALIS et al., 2001b). However, weeds with a high stomatal density in their leaves may present relatively high levels of herbicide uptake (HUANGFU et al., 2007).

By analyzing mixtures, we observed total control of B. decumbens using Roundup Original and Roundup WG + formulations (saflufenacil + Dash). Rain occurring up to 15 min after spraying the mixtures did not influence the control of plants (Table 3).

Table 2. Mean values for percentage of control of Brachiaria decumbens at 7 DAA obtained by the unfolding of degrees of freedom of the interaction between herbicides and periods without rain after the application of herbicides.

\begin{tabular}{|c|c|c|c|c|c|c|c|}
\hline \multirow{3}{*}{$\begin{array}{l}\text { Periods } \\
\text { Without rain }\end{array}$} & \multicolumn{7}{|c|}{ Treatments } \\
\hline & $\begin{array}{l}\text { saf. + R. } \\
\text { Original }^{1}\end{array}$ & $\begin{array}{c}\text { saf. + R. } \\
\text { Transorb } \mathbf{R}^{1}\end{array}$ & saf. + R. WG ${ }^{1}$ & saflufenacil $^{1}$ & R. Original & R. Transorb & R. WG \\
\hline & $\begin{array}{l}(24.5+1,080) \\
(g \text { a.i./a.e. ha-1) }\end{array}$ & $\begin{array}{l}(24.5+1,080) \\
(g \text { a.i./a.e. ha-1) }\end{array}$ & $\begin{array}{l}(24.5+1,080) \\
(g \text { a.i./a.e. ha-1) }\end{array}$ & $\begin{array}{c}(24.5) \\
\left(g \text { a.i. } \mathrm{ha}^{-1}\right)\end{array}$ & $\begin{array}{c}(1,080) \\
(g \text { a.e. ha-1) }\end{array}$ & $\begin{array}{c}(1,080) \\
\left(\mathrm{g} \text { a.e. } \mathrm{ha}^{-1}\right)\end{array}$ & $\begin{array}{c}(1,080) \\
\left(\mathrm{g} \text { a.e. } \mathrm{ha}^{-1}\right)\end{array}$ \\
\hline $15 \mathrm{~min}$ & 96.0 a A & 37.5 bc $D$ & 96.0 a $A B$ & $0.00 \mathrm{~d} A$ & 50.0 b B & $0.0 \mathrm{~d} \mathrm{C}$ & $15.0 \mathrm{~cd} \mathrm{C}$ \\
\hline $30 \mathrm{~min}$ & 99.0 a A & 53.5 bc CD & $83.0 \mathrm{ab} A B$ & $0.00 \mathrm{~d} \mathrm{~A}$ & 62.8 bc B & 47.8 c B & 47.5 c B \\
\hline 1 hour & 99.0 a A & 60.0 bc BCD & $89.5 \mathrm{ab} A B$ & $0.00 \mathrm{~d} \mathrm{~A}$ & 62.3 bc B & 46.0 c B & 62.5 bc B \\
\hline 2 hours & 99.0 a A & $81.8 a b$ ABC & 64.5 b B & $0.00 \mathrm{c} \mathrm{A}$ & 99.0 a A & 99.0 a A & 99.0 a A \\
\hline 4 hours & 99.0 a A & 85.5 a $A B$ & 99.0 a A & $0.00 \mathrm{~b} \mathrm{~A}$ & 99.0 a A & 99.0 a A & 99.0 a A \\
\hline 6 hours & 99.0 a A & 97.0 a A & 80.5 a $A B$ & $0.00 \mathrm{~b} \mathrm{~A}$ & 99.0 a A & 99.0 a A & 99.0 a A \\
\hline No Rain & 99.0 a A & 99.0 a A & 99.0 a A & $2.50 \mathrm{~b} \mathrm{~A}$ & 100.0 a A & 99.0 a A & 99.0 a A \\
\hline Treatment $(\mathrm{T})$ & & & & 123.99 ** & & & \\
\hline Rainfall (C) & & & & $33.85^{* *}$ & & & \\
\hline $\mathrm{TxC}$ & & & & $5.63^{* *}$ & & & \\
\hline CV\% & & & & 21.90 & & & \\
\hline d.m.s & & & & 12.14 & & & \\
\hline
\end{tabular}

Means followed by the same lowercase letters in rows and uppercase in columns do not differ statistically by Tukey test $(P<0.05)$; ${ }^{\prime} 0.5 \%$ Dash added, DAA: Days After Application; R: Roundup; saf.: saflufenacil; ** Significant at $1 \%$ probability level. 
The control efficiency of $B$. decumbens plants in the spray treatments using saflufenacil + glyphosate without a subsequent rain simulation corroborates the data of MARTINS et al. (2012), who observed high control rates of Commelina benghalensis and Commelina villosa using the saflufenacil + glyphosate tank mix with the Roundup Original formulation.

However, the Roundup Transorb R tank mix with saflufenacil + Dash still provided an unsatisfactory control of $B$. decumbens plants when rainfall occurred up to $15 \mathrm{~min}$ after spraying. However, it was superior to the isolated application of Roundup Transorb R (Table 3).

We observed, for the tank mix (saflufenacil + dash) and Roundup WG, that the use of saflufenacil + dash exerted a synergistic effect on the control of $B$. decumbens plants when rains occurred $15 \mathrm{~min}$ after spraying this mixture, compared to the isolated application of Roundup WG. This was because the control efficiency of $B$. decumbens plants was decreased with the occurrence of rains shortly after an isolated spraying of this herbicide (Table 3). SINGH et al. (2011) reported that the tank mix saflufenacil + glyphosate showed a greater efficacy in weed control when compared to the isolated spray of such herbicides.

At 21 DAA (Table 4), we noted that the occurrence of a 15-min rainfall after an isolated spraying of Roundup Transorb $\mathrm{R}$ and Roundup WG reduced the control efficiency of these herbicides, as well as the saflufenacil + Dash tank mix with Roundup Transorb R. It is noteworthy that the synergistic effect of saflufenacil + Dash mixed with Roundup WG was maintained when a rain occurred $15 \mathrm{~min}$ after spraying (Table 4).
EUBANK et al. (2013) evaluated the effects of the interaction between glyphosate and saflufenacil and the absorption and translocation patterns of these herbicides applied in isolation and mixed with two glyphosate-susceptible and glyphosate-resistant populations of Conyza canadensis and concluded that the glyphosate tank mix with saflufenacil, in spite of having reduced glyphosate translocation in both populations, provided a satisfactory control, achieving control levels of $100 \%$ at 21 DAA. Such results are similar to those obtained by YAMAUTI et al. (2010), in which the spray mixture of glyphosate + (bromacil + diuron) and glyphosate + diuron were efficient in the control of glyphosate-resistant Buva biotypes.

At the end of the study, at $28 \mathrm{DAA}$, we observed that the isolated saflufenacil + Dash spraying, independent of the rain period analyzed, was not effective in controlling $B$. decumbens plants (Table 5). We also verified that the isolated application of Roundup Transorb R (potassium salt) and Roundup WG (ammonium salt) may not provide an efficient control of $B$. decumbens in case rainfalls occur 15 min after spraying (Table 5).

In general, we observed that the use of saflufenacil + Dash mixed with glyphosate Roundup Transorb R and Roundup WG formulations increased the control efficiency of these formulations when rainfall occurs soon after its application. These results show that saflufenacil has a great potential for use in tank mixes with glyphosate to improve weed control levels in agricultural areas.

Table 3. Mean values for percentage of control of Brachiaria decumbens at 14 DAA obtained by the unfolding of degrees of freedom of the interaction between herbicides and periods without rain after the application of herbicides.

\begin{tabular}{|c|c|c|c|c|c|c|c|}
\hline \multirow{3}{*}{$\begin{array}{l}\text { Periods } \\
\text { Without rain }\end{array}$} & \multicolumn{7}{|c|}{ Treatments } \\
\hline & $\begin{array}{l}\text { saf. + R. } \\
\text { Original' }\end{array}$ & $\begin{array}{c}\text { saf. + R. } \\
\text { Transorb } \mathbf{R}^{1}\end{array}$ & saf. + R. WG' & saflufenacil $^{1}$ & R. Original & R. Transorb & R. WG \\
\hline & $\begin{array}{l}(24.5+1,080) \\
\left(g \text { a.i./a.e. } \text { ha }^{-1}\right)\end{array}$ & $\begin{array}{l}(24.5+1,080) \\
(g \text { a.i./a.e. ha-1) }\end{array}$ & $\begin{array}{l}(24.5+1,080) \\
\left(g \text { a.i./a.e. } \text { ha }^{-1}\right)\end{array}$ & $\begin{array}{c}(24.5) \\
\left(g \text { a.i. } \mathrm{ha}^{-1}\right)\end{array}$ & $\begin{array}{c}(1,080) \\
\left(\mathrm{g} \text { a.e. } \mathrm{ha}^{-1}\right)\end{array}$ & $\begin{array}{c}(1,080) \\
\left(g \text { a.e. } h^{-1}\right)\end{array}$ & $\begin{array}{c}(1,080) \\
\left(g \text { a.e. } \mathrm{ha}^{-1}\right)\end{array}$ \\
\hline $15 \min$ & 100.0 a A & 72.5 b B & 100.0 a A & $0.00 \mathrm{~d} A$ & 100.0 a A & $1.3 \mathrm{~dB}$ & 37.5 c B \\
\hline $30 \mathrm{~min}$ & 100.0 a $\mathrm{A}$ & 91.3 a $A B$ & 100.0 a A & $0.00 \mathrm{~b} \mathrm{~A}$ & 100.0 a $\mathrm{A}$ & 87.5 a A & 81.3 a A \\
\hline 1 hour & 100.0 a A & 93.3 a $A B$ & 100.0 a A & $0.00 \mathrm{~b} \mathrm{~A}$ & 100.0 a A & 93.8 a A & 93.8 a A \\
\hline 2 hours & 100.0 a A & 94.5 a $A B$ & 100.0 a A & $0.00 \mathrm{~b} \mathrm{~A}$ & 100.0 a $\mathrm{A}$ & 100.0 a A & 100.0 a A \\
\hline 4 hours & 100.0 a A & 98.8 a A & 100.0 a A & $0.00 \mathrm{~b} \mathrm{~A}$ & 100.0 a A & 100.0 a A & 100.0 a A \\
\hline 6 hours & 100.0 a A & 100.0 a A & 100.0 a A & $0.00 \mathrm{~b} \mathrm{~A}$ & 100.0 a A & 100.0 a A & 100.0 a A \\
\hline No Rain & 100.0 a A & 100.0 a A & 100.0 a A & $0.00 \mathrm{~b} \mathrm{~A}$ & 100.0 a A & 100.0 a A & 100.0 a A \\
\hline Treatment $(T)$ & & & & $310.99^{* *}$ & & & \\
\hline Rainfall (C) & & & & $23.12^{* *}$ & & & \\
\hline $\mathrm{TxC}$ & & & & $7.30 * *$ & & & \\
\hline CV\% & & & & 13.46 & & & \\
\hline d.m.s & & & & 8.65 & & & \\
\hline
\end{tabular}

Means followed by the same lowercase letters in rows and uppercase in columns do not differ statistically by Tukey test $(P<0.05) ;{ }^{1} 0.5 \%$ Dash added, DAA: Days After Application; R: Roundup; saf.: saflufenacil; **Significant at $1 \%$ probability level. 
Table 4. Mean values for percentage of control of Brachiaria decumbens at 21 DAA obtained by the unfolding of degrees of freedom of the interaction between herbicides and periods without rain after the application of herbicides.

\begin{tabular}{|c|c|c|c|c|c|c|c|}
\hline \multirow{3}{*}{$\begin{array}{l}\text { Periods } \\
\text { Without rain }\end{array}$} & \multicolumn{7}{|c|}{ Treatments } \\
\hline & $\begin{array}{l}\text { saf. + R. } \\
\text { Original' }\end{array}$ & $\begin{array}{c}\text { saf. + R. } \\
\text { Transorb } \mathbf{R}^{1}\end{array}$ & saf. + R. WG ${ }^{1}$ & saflufenacil' & R. Original & R. Transorb & R. WG \\
\hline & $\begin{array}{l}(24.5+1,080) \\
(g \text { a.i./a.e. ha-1) }\end{array}$ & $\begin{array}{l}(24.5+1,080) \\
(g \text { a.i./a.e. ha-1) }\end{array}$ & $\begin{array}{l}(24.5+1,080) \\
(g \text { a.i./a.e. ha-1) }\end{array}$ & $\begin{array}{c}(24.5) \\
\left(g \text { a.i. } \mathrm{ha}^{-1}\right)\end{array}$ & $\begin{array}{c}(1,080) \\
\left(\mathrm{g} \text { a.e. } \mathrm{ha}^{-1}\right)\end{array}$ & $\begin{array}{c}(1,080) \\
\left(\mathrm{g} \text { a.e. } \mathrm{ha}^{-1}\right)\end{array}$ & $\begin{array}{c}(1,080) \\
(\text { g a.e. ha-1) }\end{array}$ \\
\hline $15 \min$ & 100.0 a A & 79.8 b B & 100.0 a A & $0.00 \mathrm{c} \mathrm{A}$ & 100.0 a A & 5.0 с B & 66.8 b B \\
\hline $30 \mathrm{~min}$ & 100.0 a A & 95.0 a $A B$ & 100.0 a A & $0.00 \mathrm{~b} \mathrm{~A}$ & 100.0 a A & 90.0 a A & 86.3 a A \\
\hline 1 hour & 100.0 a A & 97.8 a $A B$ & 100.0 a A & $0.00 \mathrm{~b} \mathrm{~A}$ & 100.0 a A & 99.5 a A & 99.3 a A \\
\hline 2 hours & 100.0 a A & 97.3 a $A B$ & 100.0 a A & $0.00 \mathrm{~b} \mathrm{~A}$ & 100.0 a A & 100.0 a A & 100.0 a A \\
\hline 4 hours & 100.0 a A & 100.0 a A & 100.0 a A & $0.00 \mathrm{~b} \mathrm{~A}$ & 100.0 a A & 100.0 a A & 100.0 a A \\
\hline 6 hours & 100.0 a A & 100.0 a A & 100.0 a A & $0.00 \mathrm{~b} \mathrm{~A}$ & 100.0 a A & 100.0 a A & 100.0 a A \\
\hline No Rain & 100.0 a A & 100.0 a A & 100.0 a A & $0.00 \mathrm{~b} \mathrm{~A}$ & 100.0 a A & 100.0 a A & 100.0 a A \\
\hline Treatment $(\mathrm{T})$ & & & & $493.56^{* *}$ & & & \\
\hline Rainfall (C) & & & & 22.79 ** & & & \\
\hline $\mathrm{TxC}$ & & & & $9.16^{* *}$ & & & \\
\hline CV\% & & & & 10.62 & & & \\
\hline d.m.s & & & & 6.95 & & & \\
\hline
\end{tabular}

Means followed by the same lowercase letters in rows and uppercase in columns do not differ statistically by Tukey test $(\mathrm{P}<0.05)$; ${ }^{0.5 \%}$ Dash added, DAA: Days After Application; R: Roundup; saf.: saflufenacil; **Significant at $1 \%$ probability level.

Table 5. Mean values for percentage of control of Brachiaria decumbens at 28 DAA obtained by the unfolding of degrees of freedom of the interaction between herbicides and periods without rain after the application of herbicides.

\begin{tabular}{|c|c|c|c|c|c|c|c|}
\hline \multirow{3}{*}{$\begin{array}{l}\text { Periods } \\
\text { Without } \\
\text { rainfall }\end{array}$} & \multicolumn{7}{|c|}{ Treatments } \\
\hline & $\begin{array}{l}\text { saf. + R. } \\
\text { Original }^{1}\end{array}$ & $\begin{array}{c}\text { saf. + R. } \\
\text { Transorb } \mathbf{R}^{1}\end{array}$ & saf. + R. WG' & saflufenacil ${ }^{1}$ & R. Original & R. Transorb & R. WG \\
\hline & $\begin{array}{l}(24.5+1,080) \\
(\text { g a.i./a.e. ha-1) }\end{array}$ & $\begin{array}{l}(24.5+1,080) \\
(g \text { a.i./a.e. ha-1) }\end{array}$ & $\begin{array}{l}(24.5+1,080) \\
(g \text { a.i./a.e. ha-1) }\end{array}$ & $\begin{array}{c}(24.5) \\
\left(\mathrm{g} \text { a.i. } \mathrm{ha}^{-1}\right)\end{array}$ & $\begin{array}{c}(1,080) \\
\left(g \text { a.e. } h^{-1}\right)\end{array}$ & $\begin{array}{c}(1,080) \\
\left(g \text { a.e. } h^{-1}\right)\end{array}$ & $\begin{array}{c}(1,080) \\
\left(g \text { a.e. } h^{-1}\right)\end{array}$ \\
\hline $15 \mathrm{~min}$ & 100.0 a A & 87.5 b B & 100.0 a A & $0.00 \mathrm{~d} A$ & 100.0 a A & 22.5 c B & 87.5 b B \\
\hline $30 \mathrm{~min}$ & 100.0 a A & 100.0 a $A$ & 100.0 a A & $0.00 \mathrm{~b} \mathrm{~A}$ & 100.0 a A & 99.8 a A & 99.8 a A \\
\hline 1 hour & 100.0 a A & 100.0 a A & 100.0 a $A$ & $0.00 \mathrm{~b} \mathrm{~A}$ & 100.0 a $A$ & 100.0 a $A$ & 99.8 a A \\
\hline 2 hours & 100.0 a A & 100.0 a A & 100.0 a A & $0.00 \mathrm{~b} \mathrm{~A}$ & 100.0 a A & 100.0 a A & 100.0 a A \\
\hline 4 hours & 100.0 a A & 100.0 a A & 100.0 a $A$ & 0.00 b A & 100.0 a A & 100.0 a $A$ & 100.0 a $\mathrm{A}$ \\
\hline 6 hours & 100.0 a A & 100.0 a A & 100.0 a $A$ & $0.00 \mathrm{~b} \mathrm{~A}$ & 100.0 a A & 100.0 a A & 100.0 a A \\
\hline No Rain & 100.0 a A & 100.0 a A & 100.0 a A & $0.00 \mathrm{~b} \mathrm{~A}$ & 100.0 a $A$ & 100.0 a A & 100.0 a $\mathrm{A}$ \\
\hline Treatment $(\mathrm{T})$ & & & & $2,599.04^{* *}$ & & & \\
\hline Rainfall (C) & & & & $57.77^{* *}$ & & & \\
\hline $\mathrm{TxC}$ & & & & $30.95^{* *}$ & & & \\
\hline CV\% & & & & 4.60 & & & \\
\hline d.m.s & & & & 3.07 & & & \\
\hline
\end{tabular}

Means followed by the same lowercase letters in rows and uppercase in columns do not differ statistically by Tukey test $(P<0.05) ;{ }^{1} 0.5 \%$ Dash added, DAA: Days After Application; R: Roundup; saf.: saflufenacil; **Significant at $1 \%$ probability level. 


\section{CONCLUSIONS}

The mixture of saflufenacil + Dash with original Roundup, Roundup Transorb R and Roundup WG formulations increased the control speed of Brachiaria decumbens plants regardless of the rain periods studied. Formulations of glyphosate (Roundup Transorb R and Roundup WG) applied in isolation are affected by rainfalls occurring shortly after spraying. The use of saflufenacil in the tank mix with Roundup Transorb R and Roundup WG formulations increased weed control when rainfalls occurred shortly after spraying. Saflufenacil + Dash showed a synergistic effect when mixed with the glyphosate formulations Roundup Transorb R and Roundup WG.

| | | | | | | | | | | | | | | | | | | | | | | | | | | | | | | | | | | | | | | | | | | | | | | | | | | | | | | | | | | | | | | | | | | | | | | | | | | | | | | | | | | | | | | | | | | | | | | | | | | | | | | | | | | | | | | | | | | | | | | | | | | | | | | | | | | | | | | | | | | | | | | | | | | | | | | | | | | | | | | | | | | | | | | | | | | | | | | | | | | | | | | | | | | | | | | | | | | | | | | | | | | | | | | | || || REFERENCES

ALONSO, D.G.; CONSTANTIN, J.; OLIVEIRA JR., R.S.; SANTOS, G.; DAN, H.A.; OLIVEIRA NETO, A.M. Selectivity of glyphosate alone or in mixtures for RR soybean in sequential applications. Planta Daninha, v.31, n.1, p.203-212, 2013.

CARVALHO, L.B.; HIPOLITO, H.C.; TORRALVA, F.G.; ALVES, P.L.C.A.; CHRISTOFFOLETI, P.J.; PRADO, R. Detection of sourgrass (Digitaria insularis) biotypes resistant to glyphosate in Brazil. Weed Science, v.59, n.2, p.171-176, 2011.

CHACHALIS, D.; REDDY, K.N.; ELMORE, C.D. Characterization of leaf surface, wax composition, and control of redvine and trumpetcreeper with glyphosate. Weed Science, v.49, n.2, p.156-163, 2001a.

CHACHALIS, D.; REDDY, K.N.; ELMORE, C.D.; STEELE, M.L. Herbicide efficacy, leaf structure, and spray droplet contact angle among Ipomoea species and smallflower morningglory. Weed Science, v.49, n.5, p.628-634, 2001 b.

EUBANK, T.W.; NANDULA, V.K.; REDDY, K.N.; POSTON, D.H.; SHAW, D.R. Saflufenacil efficacy on horseweed and its interaction with glyphosate. Weed Biology and Management, v.13, n.4, p. 135-143, 2013.

FENG, C.C.P.; SANDBRINK, J.J.; SAMMONS, D.R. Retention, uptake, and translocation of ${ }^{14} \mathrm{C}$-glyphosate from trackspray applications and correlation to rainfastness in velvetleaf (Abutilon theophrasti). Weed Technology, v.14, n. 1, p.127-132, 2000.

GAINES, T.A.; CRIPPS, A.; POWLES, S.B. Evolved resistance to glyphosate in junglerice (Echinochloa colona) from the Tropical Ord River Region in Australia. Weed Technology, v.26, n.3, p.480-484, 2012.

GONÇALVES, C.G.; SILVA JR., A.C.D.S.; PEREIRA, M.R.R.; MARCHI, S.R.; MARTINS, D. Selectivity of saflufenacil applied singly and in combination with glyphosate on coffee and citrus crops. Caatinga, v.29, n. 1, p.45-53, 2016.

GROSSMANN, K.; NIGGEWEG, R.; CHRISTIANSEN, N.; LOOSER, R.; EHRHARDT, T. The herbicide saflufenacil (Kixor ${ }^{\mathrm{TM}}$ ) is a new inhibitor of protoporphyrinogen IX oxidase activity. Weed Science, v.58, n. 1, p.1-9, 2010.
HUANGFU, C.H.; SONG, X.L.; QIANG, S.; ZHANG, H.J. Response of wild Brassica juncea populations to glyphosate. Pest Management Science, v.63, n.11, p.1133-1140, 2007.

JONES, A.P.; PARQUE, K.W.; COLQUHOUN, J.; SMITH, C.M.; SHANER, D. Identification of glyphosate-resistant Italian ryegrass (Lolium multiflorum) in Oregon. Weed Science, v.53, n.6, p.775-779, 2005.

KIRKWOOD, R.C.; MCKAY, I. Extended summaries SCI pesticides group symposium current themes in pharmaceuticals and agrochemicals: Principles and differences. Accumulation and elimination of herbicides in selected crop and weed species. Pesticide Science, v.42, n.3, p.241-251, 1994.

MACIEL, C.D.G.; POLETINE, J.P.; AMSTALDEN, S.L.; GAZZIERO, D.L.P.; RAIMONDI, M.A.; LIMA, G.R.G.; OLIVEIRA NETO, A.M.; GUERRA, N.; JUSTINIANO, W. Misturas em tanque com glyphosate para o controle de trapoeraba,erva-de-touro e capim-carrapicho em soja RR ${ }^{\varpi}$. Ceres, v.58, n. 1, p.35-42, 2011.

MARTINI, G.; PEDRINHO JR., A.F.F.; DURIGAN, J.C. Eficácia do herbicida glifosato-potássico submetido à chuva simulada após a aplicação. Bragantia, v.62, n. 1, p.39-45, 2003.

MARTINS, D.; SANTANA, D.C.; SOUZA, G.S.F.; BAGATTA, M.V.B. Manejo químico de espécies de trapoeraba com aplicação isolada e em mistura de diferentes herbicidas. Caatinga, v.25, n.2, p.21-28, 2012.

MONQUERO, P.A.; SILVA, A.C. Efeito do período de chuva no controle de Euphorbia heterophylla e Ipomoea purpurea pelos herbicidas glyphosate e sulfosate. Planta Daninha, v.25, n.2, p.399-404, 2007.

OWEN, M.D.K. Weed species shifts in glyphosate-resistant crops. Pest Management Science, v.64, n.4, p.377-387, 2008.

RAIJ, B.V.; CANTARELLA, H.; GUAGGIO, J.A.; FURLANI, A.M.C. Recomendações de adubação e calagem para o Estado de São Paulo. 2. ed. Campinas: IAC, 1996. 285p. (IAC. Boletim Técnico, 100).

SILVA, A.F.; CONCENÇO, G.; ASPIAZÚ, I.; FERREIRA, E.A.; GALON, L.; COELHO, A.T.C.P.; SILVA, A.A.; FERREIRA, F.A. Interferência de plantas daninhas em diferentes densidades no crescimento da soja. Planta Daninha, v.27, n.1, p.75-84, 2009. 
SILVA, A.F.; FERREIRA, E.A.; CONCENÇO, G.; FERREIRA, F.A.; ASPIAZU, I.; GALON, L.; SEDIYAMA, T.; SILVA, A.A. Densidades de plantas daninhas e épocas de controle sobre os componentes de produção da soja. Planta Daninha, v.26, n. 1, p.65-7 1, 2008.

SINGH, M.; MALIK, M.; RAMIREZ, A.H.; JHALA, A.J. Tank mix of saflufenacil with glyphosate and pendimethalin for broadspectrum weed control in Florida citrus. HortTechnology, v.21, n.5, p.606-615, 2011.

\section{SOCIEDADE BRASILEIRA DA CIÊNCIA DAS PLANTAS DANINHAS} (SBCPD). Procedimentos para instalação, avaliação e análise de experimentos com herbicidas. Londrina: SBCPD, 1995. 42p.

SOUZA, G.S.F.; MARTINS, D.; PEREIRA, M.R.R. Efeito da chuva na eficiência de herbicidas aplicados em pós-emergência sobre corda-de-viola. Planta Daninha, v.31, n. 1, p.175-184, 2013.
SOUZA, G.S.F.; MARTINS, D.; PEREIRA, M.R.R.; BAGATTA, M.V.B. Action of rain on the efficiency of herbicides applied postemergence in the control of Senna obtusifolia. Ciência Agronômica, v.45, n.3, p.550-557, 2014.

STEWART, C.L.; NURSE, R.E.; VAN EERD, L.L.; VYN, R.J.; SIKKEMA, P.H. Weed control, environmental impact, and economics of weed management strategies in glyphosate-resistant soybean. Weed Technology, v.25, n.4, p.535-541, 2011.

VILA-AIUB, M.M.; BALBI, M.C.; GUNDEL, P.E.; GHERSA, C.M.; POWLES, S.B. Evolution of glyphosate-resistant Johnsongrass (Sorghum halepense) in glyphosate-resistant soybean. Weed Science, v.55, n.6, p.566-571, 2007.

YAMAUTI, M.S.; BARROSO, A.A.M.; SOUZA, M.C.; ALVES, P.L.C.A. Controle químico de biótipos de buva (Conyza canadensis e Conyza bonariensis) resistentes ao glyphosate 1. Ciência Agronômica, v.41, n.3, p.495-500, 2010.

Arquivos do Instituto Biológico, vol. 84, Action of rain on formulations of glyphosate mixed with saflufenacil for the control of Brachiaria decumbens, http://dx.doi.org/10.1590/1808-1657000172015, inserção dos nomes completos dos autores.

No artigo Action of rain on formulations of glyphosate mixed with saflufenacil for the control of Brachiaria decumbens, com número de DOI: http://dx.doi.org/10.1590/1808-1657000172015, publicado no periódico Arquivos do Instituto Biológico, 84: e0172015 na página 1:

Onde se lia:

"Andréia Cristina Rodrigues da Costa ${ }^{1}$, Clebson Gonçalves ${ }^{2 *}$, Antonio da Silva Júnior ${ }^{2}$, Leonildo Cardoso³ , Dagoberto Martins"”

Leia-se:

"Andréia Cristina Rodrigues da Costa ${ }^{1}$, Clebson Gomes Gonçalves²*, Antonio Carlos da Silva Junior ${ }^{2}$, Leonildo Cardoso ${ }^{3}$, Dagoberto Martins" 